\title{
ANALISIS J ALUR FAKTOR-FAKTOR YANG MEMPENGARUHI KETAHANAN PANGAN RUMAH TANGGA DI KABUPATEN LEBAK, PROPINSI BANTEN
}

\author{
(Path Analysis: Determinant Factors of Household Food Security in Lebak District, \\ Banten Province) \\ Ikeu Tanziha ${ }^{1 *}$ dan Eka Herdiana ${ }^{2}$ \\ 1* Departemen Gizi Masyarakat, Fakultas Ekologi Manusia, Institut Pertanian Bogor, Bogor 16680 \\ Tel: 0251-8621258; Fax: 8622276; Email: ikeu_jamilah@yahoo.co.id \\ 2 Program Studi Gizi Masyarakat, Fakultas Ekologi Manusia, Institut Pertanian Bogor, Bogor 16680
}

\begin{abstract}
ABST RACT
The objective of the study was to analyze direct and indirect factors that influence household's food security. The study design was a crosectional study. Research was conducted in Pasindangan and Banjarsari Village, Cileles and Warunggunung Subdistrict, Lebak Distric, Banten Province in April - May 2009. A purposive sampling was applied to select 101 households. The data collected include socio economy and food intake. Quantitatively, a household is categorized as food security, if his/ her TKE $>90 \%$ and a household is categorized as food insecurity, if his/ her TKE <90\% The Rank Spearman test was applied to analyze correlation of socioeconomic, demographic and food intake variables between food securities. Path analysis was used to analyze direct and indirect factors that influence household's food security. The results showed that $62.4 \%$ households were food security, and $37.6 \%$ households were food insecurity. There are correlation between household expenditure per capita, number of household member and land area to household food security. Based on the path analysis, direct factor that influence household food security was household expenditure per capita. Indirect factors that influence household food security were number of household member - household expenditure per capita - household food security.
\end{abstract}

Keywords: food security, path analysis, and socio economic

\section{PENDAHULUAN}

Pada masalah ketahanan yang berat, tidak hanya dari sisi ketersediaan dan distribusi tetapi juga dari sisi konsumsi. Khususnya provinsi banten, rata-rata konsumsi energi per kapita per hari baru mencapai 1371.5 kalori atau $<70 \%$ tingkat kecukupan energi (TKE) yang dianjurkan, dan masih jauh dari rata-rata konsumsi energi nasional yaitu 1735.5 kalori. Kondisi ini salah satunya disebabkan karena provinsi Banten khususnya Lebak sebagian besar penduduknya (64.26\%) bermatapencaharian sebagai petani $(41.64 \%)$ dan buruh tani $(22.62 \%)$, yang bertempat tinggal di pedesaan. Data BPS (2008) menunjukkan bahwa sebagian besar penduduk miskin $(63.47 \%)$ berada di daerah pedesaan.

Lebih lanjut BPS (2008) menunjukkan bahwa Nilai Indeks Kedalaman Kemiskinan dan Indeks Keparahan Kemiskinan di daerah perdesaan lebih tinggi dari pada perkotaan. Pada bulan Maret 2008, nilai Indeks Kedalaman Kemiskinan untuk perkotaan hanya 2.07 sementara di daerah pedesaan mencapai 3.42. Nilai
Indeks Keparahan Kemiskinan untuk perkotaan hanya 0.56 sementara di daerah pedesaan mencapai 0.95. Dapat disimpulkan bahwa tingkat kemiskinan di daerah pedesaan lebih parah dari pada daerah perkotaan.

Penduduk miskin di Kabupaten Lebak terus meningkat, pada tahun 2004 penduduk miskin di Kabupaten Lebak sebanyak 138000 jiwa, tahun 2005 meningkat menjadi 141000 jiwa, tahun 2006 meningkat lagi menjadi 172440 jiwa atau 14.4\% (BPS Banten 2007). Demikian pula terdapat peningkatan jumlah pengangguran dari 14159 jiwa pada tahun 2006 menjadi 18286 jiwa pada tahun 2007. Kondisi ini akan berimplikasi pada menurunnya ketahanan pangan rumah tangga.

Berbagai upaya pemerintah telah dilakukan untuk meningkatkan ketahanan pangan rumah tangga, diantaranya PNPM. Selama periode Maret 2007-Maret 2008, penduduk miskin di daerah pedesaan berkurang 1.42 juta orang, sementara di daerah perkotaan berkurang 0.79 juta orang. Namun Persentase penduduk miskin antara daerah perkotaan dan pedesaan tidak banyak berubah. Pada bulan Maret 2008, 
sebagian besar (63.47\%) penduduk miskin berada di daerah pedesaan (BPS, 2008).

Menurut Bomer (2008) bahwa dalam meningkatkan ketahanan pangan penduduk tidak bisa hanya dari sisi pendapatan saja, tetapi harus melihat pada aspek lain yang saling terkait. Dengan demikian pada penelitian ini dianalisis berbagai faktor baik yang berpengaruh langsung maupun tidak langsung pada ketahanan rumah tangga.

Tujuan yang ingin dicapai dalam penelitian ini adalah (1) Menganalisis konsumsi dan prevalensi rumah tangga tahan dan rawan pangan, (2) Menganalisis hubungan faktor sosial ekonomi sebagai akses pangan dengan ketahanan pangan rumah tangga, dan (3) Menganalisis faktor sosial ekonomi yang berpengaruh langsung dan tidak langsung terhadap ketahanan pangan rumah tangga.

\section{METODE}

\section{Desain, Tempat dan Waktu}

Penelitian ini merupakan bagian dari penelitian "Model Penguatan Modal Komunitas Pertanian Dalam Upaya Pencegahan dan Penanggulangan Kelaparan" yang dilaksanakan di Kabupaten Lebak, Banten" Kerjasama IPB dan Badan Litbang Departemen Pertanian. Penelitian ini menggunakan desain cross sectional study, berlokasi di Kabupaten Lebak Propinsi Banten, yang dilakukan pada bulan April sampai dengan Mei 2009.

\section{J umlah dan Cara Penarikan Contoh}

Penarikan contoh dilakukan secara purposive, yaitu dipilih dua Kecamatan di wilayah Kabupaten Lebak yang merupakan daerah pertanian tipologi kecamatan tipe 3 (tingkat kesejahteraan rendah, sektor nonfarm rendah) dan tipologi kecamatan tipe 2 (tingkat kesejahteraan tinggi, sektor nonfarm rendah). Dari tiap kecamatan dipilih masing-masing satu desa yang mewakili tipologi kecamatan. Contoh berjumlah 101 rumah tangga, dengan kriteria (1) pekerjaan utama kepala rumah tangga sebagai petani, (2) contoh mewakili populasi berdasarkan proposi kepemilikan lahan, yaitu petani tidak memiliki lahan (buruh tani), dan petani memiliki lahan kurang dari $5000 \mathrm{~m}^{2}, 5000$ $10000 \mathrm{~m}^{2}$, dan $>10000 \mathrm{~m}^{2}$.

\section{J enis dan Cara Pengumpulan Data}

Data yang dikumpulkan berupa data primer dan data sekunder. Data primer merupa- kan data sosial ekonomi rumah tangga meliputi, besar keluarga, lama pendidikan formal kepala dan ibu rumah tangga, pendapatan rumah tangga, akses pangan dan konsumsi pangan. Data primer diperoleh melalui wawancara dengan kuesioner yang terstruktur. Data sekunder yang dikumpulkan antara lain gambaran umum lokasi penelitian dan data demografi.

\section{Pengolahan dan Analisis Data}

Proses pengolahan data meliputi editing, coding, entry dan analisis. Untuk mengukur hubungan antara variabel dianalisis menggunakan analisis korelasi pearson dan rank Spearman, sedangkan untuk mengukur pengaruh antara variabel-variabel penelitian dianalis dengan menggunakan analisis jalur.

Ukuran rumah tangga dikategorikan berdasarkan ketentuan BKKBN. Rumah tangga kecil jika terdiri dari $\leq 4$ orang, sedang jika 5-6 orang, dan besar jika $\geq 7$ orang. Pengeluaran rumah tangga dikategorikan jadi dua kategori yaitu "miskin" jika pengeluaran per kapita di bawah garis kemiskinan dan "tidak miskin" jika di atas garis kemiskinan. Pengetahuan gizi ibu dikategorikan menjadi tiga, yaitu "rendah" bila skor $\leq 5$, "sedang" bila skor 6-7, dan "tinggi" bila skor $\geq 8$. Dukungan sosial dikategorikan menjadi tiga, yaitu "buruk" bila skor $<15$, "sedang" bila skor 15-20, dan "tinggi" bila skor $>20$.

Tingkat konsumsi energi dan protein dikategorikan menjadi lima berdasarkan Depkes (1996), yaitu defisit berat $(<70 \%)$, defisit sedang $(70-79 \%)$, defisit ringan $(80-89 \%)$, baik $\geq 90 \%$. Ketahanan pangan rumah tangga diperoleh dari rata-rata tingkat kecukupan energi anggota rumah tangga dengan pengkategorian berdasarkan FAO (2003) yaitu rawan pangan berat $(<70)$, rawan pangan sedang $(70-80)$, rawan pangan ringan (81-90) dan tahan pangan $(>90)$. Kemudian variabel-variabel sosial ekonomi rumah tangga dianalisis menggunakan analisis jalur dengan diagram jalur seperti pada Gambar 1.

Menurut Yamin dan Kurniawan (2009), dalam analisis jalur terdapat pengaruh tidak langsung. Besarnya pengaruh tidak langsung suatu variabel terhadap variabel tertentu dapat dihitung dengan cara mengalikan koefisien-koefisien regresi (beta- $B$ ) dari variabel pemberi efek. 


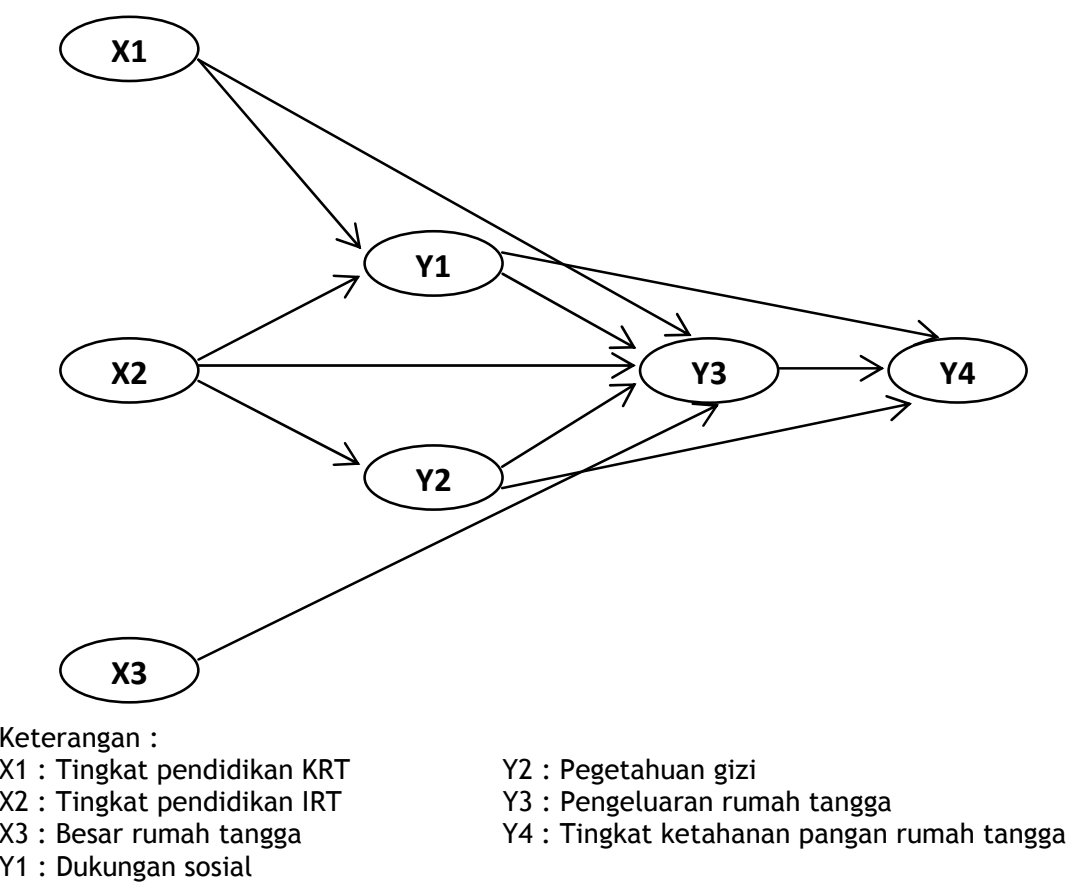

Gambar 1. Model Analisis Jalur Faktor-faktor yang Mempengaruhi Ketahanan Pangan Rumah Tangga

\section{HASIL DAN PEMBAHASAN}

\section{Konsumsi dan Ketahanan Pangan Rumah Tangga}

Rata-rata tingkat kecukupan energi (TKE) rumah tangga sudah baik yaitu $141.08 \pm$ $99.163 \%$, demikian pula untuk rata-rata tingkat kecupukan protein (TKP) $104.42 \pm 65.859 \%$. Bila TKE dan TKP dikelompokkan ke dalam defisit berat, defisit sedang, defisit ringan, dan baik, maka terlihat dari Tabel 1 bahwa sebagian besar contoh $(62.4 \%)$ dan $(52.5 \%)$ mempunyai TKE dan TKP dalam kategori baik $(\geq 90 \%)$, namun demikian ada $25.7 \%$ dan $35.6 \%$ contoh dengan TKE dan TKP dalam kondisi defisit berat (<70\%) (Tabel 1).

Tabel 1. Sebaran Contoh menurut Tingkat Kecukupan Energi dan Protein

\begin{tabular}{lcccc}
\hline \multirow{2}{*}{ Tingkat Kecukupan } & \multicolumn{4}{c}{ Zat Gizi } \\
\cline { 2 - 5 } & \multicolumn{2}{c}{ Energi } & \multicolumn{2}{c}{ Protein } \\
\cline { 2 - 5 } & $\mathbf{n}$ & $\%$ & $\mathbf{n}$ & $\%$ \\
\hline Defisit berat : $<70 \%$ & 26 & 25.7 & 36 & 35.6 \\
Defisit sedang : 70-79\% & 5 & 5.0 & 8 & 7.9 \\
Defisit ringan : 80-89\% & 6 & 5.9 & 4 & 4.0 \\
Baik : $\geq 90$ & 64 & 62.4 & 53 & 52.5 \\
\hline Total & 101 & 100.0 & 101 & 100.0 \\
\hline \multirow{2}{*}{ Rataan } & $141.08 \pm$ & $104.42 \pm$ \\
& 99.163 & 65.859 \\
\hline
\end{tabular}

Bila TKE digunakan untuk mengukur ketahanan pangan rumah tangga yaitu tahan pa- ngan bila $>90 \%$ TKE, rawan pangan ringan (8190\% TKE), rawan pangan sedang (70-80\% TKE), dan rawan pangan berat (<70 TKE) (FAO, 2003), maka berdasarkan pengelompokan tersebut (Tabel 2), baik di desa Pasindangan maupun Banjarsari rumah tangga yang mengalami rawan pangan cukup tinggi yaitu 32\% dan $43.1 \%$ atau rata-rata $37.6 \%$ yang terdiri atas $6.9 \%$ rawan pangan ringan, $5.0 \%$ rawan pangan sedang dan $25.7 \%$ rawan pangan berat.

Tabel 2. Sebaran Contoh menurut Status Ketahanan Pangan

\begin{tabular}{lcccccc}
\hline \multirow{2}{*}{ Status } & \multicolumn{2}{c}{ Pasindangan } & \multicolumn{2}{c}{ Banjarsari } & \multicolumn{2}{c}{ Total } \\
\cline { 2 - 7 } & $\mathbf{n}$ & $\%$ & $\mathbf{n}$ & $\%$ & $\mathbf{n}$ & $\%$ \\
\hline Tahan pangan & 34 & 68.0 & 29 & 56.9 & 63 & 62.4 \\
Rawan Pangan : & & & & & & \\
$\quad$ Ringan & 4 & 8.0 & 3 & 5.9 & 7 & 6.9 \\
$\quad$ Sedang & 1 & 2.0 & 4 & 7.8 & 5 & 5.0 \\
$\quad$ Berat & 11 & 22.0 & 15 & 29.4 & 26 & 25.7 \\
\hline Jumlah & 50 & 100.0 & 51 & 100.0 & 101 & 100.0 \\
\hline
\end{tabular}

\section{Akses Pangan Rumah tangga}

Akses pangan tingkat rumah tangga ialah kemampuan suatu rumah tangga untuk memperoleh pangan yang cukup secara terusmenerus melalui berbagai cara, seperti produksi pangan rumah tangga, persediaan pangan rumah tangga, jual-beli, tukar-menukar/ barter, pinjam-meminjam, dan pemberian, atau bantuan pangan (WFP, 2005). Akses pangan merupakan salah satu dimensi dari 3 di- 
mensi ketahanan pangan, selain katersediaan pangan dan penyerapan pangan, dan dikategorikan menjadi akses fisik, akses ekonomi dan sosial (Deptan, 2007).

\section{Akses Fisik}

Akses fisik akan menentukan apakah sumber pangan yang dikonsumsi akan dapat ditemui dan mudah diperoleh. Kemudahan dalam memperoleh pangan ditunjang oleh tersedianya sarana fisik yang cukup dalam memperoleh pangan diantaranya adalah kepemilikan lahan.

\section{Kepemilikan Lahan}

Luas lahan yang dimiliki contoh berkisar antara 0 - $20000 \mathrm{~m}^{2}$ dengan rataan $3471.49 \pm$ $4846.33 \mathrm{~m}^{2}$. (Tabel 3). Baik di Desa Pasindangan maupun Banjarsari luas lahan yang dimiliki contoh berkisar antara $0-20000 \mathrm{~m}^{2}$, namun rata-rata luas lahan yang dimiliki di Desa $\mathrm{Pa}$ sindangan lebih luas yaitu $4592 \pm 4755956 \mathrm{~m}^{2}$ dibanding di Desa Banjarsari $2372.94 \pm$ $4724.47 \mathrm{~m}^{2}$. Bila luas lahan yang dimiliki dikelompokkan menjadi: tidak punya lahan $(0$ $\mathrm{m}^{2}$ ), $<5$ ribu $\mathrm{m}^{2}, 5-10$ ribu $\mathrm{m}^{2}$ dan $>10$ ribu $\mathrm{m}^{2}$, maka proporsi terbesar $36.6 \%$ contoh dalam kondisi tidak mempunyai lahan, menyusul $32.7 \%$ memiliki lahan < 5 ribu $\mathrm{m}^{2}, 20.8 \%$ mempunyai lahan antara $5000-10000 \mathrm{~m}^{2}$ dan hanya $9.9 \%$ contoh yang memiliki lahan $>10$ ribu $\mathrm{m}^{2}$ (Tabel 3).

Tabel 3. Sebaran Contoh menurut Luas Lahan yang Dimiliki

\begin{tabular}{lcccccc}
\hline $\begin{array}{c}\text { Luas } \\
\text { Lahan yg } \\
\text { Dimiliki }\end{array}$ & $\mathbf{n}$ & $\%$ & $\mathbf{n}$ & $\%$ & $\mathbf{n}$ & $\%$ \\
\cline { 2 - 7 } & 12 & 24.0 & 25 & 49.0 & 37 & 36.6 \\
\hline 0 & 14 & 28.0 & 19 & 37.3 & 33 & 32.7 \\
$<5$ ribu & 17 & 34.0 & 4 & 7.8 & 21 & 20.8 \\
$5-10$ ribu & 7 & 14.0 & 3 & 5.9 & 10 & 9.9 \\
$>10$ ribu & 50 & 100.0 & 51 & 100.0 & 101 & 100.0 \\
\hline Jumlah & $0-20000$ & $0-20$ & 000 & $0-20$ & 000 \\
\hline Min-max & $4592 \pm$ & $2372.94 \pm$ & $3471.49 \pm$ \\
\hline Rataan & 4755.96 & 4724.47 & 4846.33 \\
\hline
\end{tabular}

Bila luas lahan yang dimiliki dihubungkan dengan status ketahanan pangan, maka terlihat dari Tabel 4 bahwa sebagian besar (61.6\%) rumah tangga rawan pangan berat tidak mempunyai lahan, mereka hanya bekerja sebagai buruh tani. Demikian pula pada rumah tangga rawan pangan sedang sebanyak $80 \%$ terkategori dalam kepemilikan lahan < 5 ribu $\mathrm{m}^{2}$ dan tidak memiliki lahan. Tetapi pada rumah tangga rawan pangan ringan dan tahan pangan terlihat ada $14.3 \%$ dan $12.7 \%$ memiliki lahan garapan $>10000 \mathrm{~m}^{2}$.

Berdasarkan analisis korelasi Spearman diperoleh $r=0.273$ dan $p<0.01$ antara kepemilikan luas lahan dengan ketahanan pangan rumah tangga. Hasil tersebut menunjukkan bahwa terdapat hubungan positif yang signifikan antara kepemilikan luas lahan dengan ketahanan pangan rumah tangga. Semakin luas lahan yang dimiliki maka semakin besar peluang tercapainya ketahanan pangan rumah tangga.

\section{Akses Sosial}

Akses sosial rumah tangga terhadap pangan merupakan suatu akses/cara untuk mendapatkan pangan yang dibutuhkan dalam pemenuhan kebutuhan pangannya melalui sumber daya sosial (umur, pendidikan, jumlah anggota rumah tangga, pengetahuan gizi) dan berbagai dukungan sosial, seperti bantuan/dukungan sosial dari keluarga/kerabat, tetangga, serta teman.

\section{Umur Kepala Rumah tangga (KRT) dan lbu Rumah tangga (IRT).}

Umur kepala rumah tangga berkisar antara 26-85 tahun, dan rataan $46.44 \pm 11.87$, dengan proporsi terbesar (57.4\%) ada pada kelompok dewasa madya (40-59 tahun), menyusul $26.7 \%$ dalam kategori umur dewasa awal dan $\mathbf{1 5 . 8 \%}$ lansia. Hampir sama dengan umur KRT, umur IRT berkisar antara 20-75 tahun, dan rataan $40.78 \pm 10.643$, dengan proporsi terbesar $(47.5 \%)$ pada kelompok umur dewasa madya (40-59 tahun), menyusul $46.5 \%$ dalam kelompok umur dewasa awal dan 5.9\% lansia.

Tabel 4. Sebaran Rumah Tangga Berdasarkan Kepemilikan Luas Lahan dan Ketahanan Pangan

\begin{tabular}{|c|c|c|c|c|c|c|c|c|c|c|}
\hline \multirow{3}{*}{$\begin{array}{c}\text { Luas Lahan yang } \\
\text { Dimiliki }\end{array}$} & \multicolumn{8}{|c|}{ Tingkat Ketahanan Pangan } & & \\
\hline & \multicolumn{2}{|c|}{$\begin{array}{c}\text { Rawan Pangan } \\
\text { Berat }\end{array}$} & \multicolumn{2}{|c|}{$\begin{array}{c}\text { Rawan Pangan } \\
\text { Sedang }\end{array}$} & \multicolumn{2}{|c|}{$\begin{array}{c}\text { Rawan Pangan } \\
\text { Ringan }\end{array}$} & \multicolumn{2}{|c|}{ Tahan Pangan } & \multicolumn{2}{|c|}{ Total } \\
\hline & $n$ & $\%$ & $n$ & $\%$ & $\mathbf{n}$ & $\%$ & $\mathbf{n}$ & $\%$ & $\mathbf{n}$ & $\%$ \\
\hline 0 & 16 & 61.6 & 2 & 40.0 & 2 & 28.6 & 17 & 27.0 & 37 & 36.6 \\
\hline$<5000$ & 5 & 19.2 & 2 & 40.0 & 3 & 42.9 & 23 & 36.5 & 33 & 32.7 \\
\hline $5000-10000$ & 5 & 19.2 & 1 & 20.0 & 1 & 14.3 & 15 & 23.8 & 21 & 20.8 \\
\hline Jumlah & 26 & 100.0 & 5 & 100.0 & 7 & 100.0 & 63 & 100.0 & 101 & 100.0 \\
\hline
\end{tabular}




\section{Pendidikan KRT dan IRT}

Berdasarkan lama sekolah formal yang ditempuh, lama sekolah KRT berkisar antara 012 tahun, dengan rataan $5.05 \pm 3.001$, atau sebagian besar (73.3\%) berpendidikan SD. Lama sekolah IRT berkisar antara 0-16 tahun dengan rataan $4.35 \pm 3.119$. Baik di desa Pasindangan maupun di Banjarsari sebagian besar $66.0 \%$ dan $72.5 \%$ IRT berpendidikan SD. Bila dihubungkan pendidikan KRT dan IRT dengan ketahanan pangan rumah tangga, maka terlihat dari Tabel 5 bahwa sebagian besar pendidikan KRT maupun IRT hanya sampai SD dan tamat SD baik pada kategori rumah tangga rawan pangan berat, sedang, maupun ringan dan tahan pangan.

Berdasarkan analisis korelasi Spearman menunjukkan bahwa tidak terdapat hubungan yang signifikan $(r=-0.040, p>0.05)$ antara pendidikan KRT dengan ketahanan pangan rumah tangga. Begitu pun untuk pendidikan IRT, tidak terdapat hubungan yang signifikan $(r=0.027$, $p>0.05)$ antara pendidikan IRT dengan ketahanan pangan rumah tangga.

\section{J umlah Anggota Rumah tangga}

Berdasarkan pengelompokan jumlah anggota rumah tangga, maka proporsi terbesar rumah tangga contoh $(49.5 \%)$ merupakan rumah tangga kecil ( $\leq 4$ orang), $29.7 \%$ contoh merupakan rumah tangga sedang (5-6 orang), dan sisanya $(20.8 \%)$ merupakan rumah tangga besar ( $\geq 7$ orang). Bila jumlah anggota rumah tangga dihubungkan dengan status ketahanan pangan rumah tangga, maka terlihat dari Tabel 6 , bahwa sebagian besar baik pada rumah tangga tahan pangan $(60.3 \%)$ maupun rumah tangga rawan pangan ringan $(57.1 \%)$ mempunyai jumlah anggota rumah tangga $\leq 4$ orang. Sebaliknya baik pada rumah tangga rawan pangan sedang maupun berat proporsi terbesar $80.0 \%$ dan $38.5 \%$ mempunyai jumlah anggota rumah tangga 5-6 orang, bahkan pada rumah tangga rawan pangan berat sebanyak $34.6 \%$ mempunyai jumlah anggota rumah tangga $\geq 7$ orang.

Berdasarkan analisis korelasi Spearman terdapat hubungan negatif $(r=-0.261, p<0.01)$ antara jumlah anggota rumah tangga dengan ketahanan pangan rumah tangga. Hasil tersebut menunjukkan bahwa semakin besar jumlah

Tabel 5. Sebaran Rumah Tangga Berdasarkan Ketahanan Pangan dan Pendidikan KRT dan IRT

\begin{tabular}{|c|c|c|c|c|c|c|c|c|c|c|}
\hline \multirow{3}{*}{$\begin{array}{c}\text { Tingkat } \\
\text { Pendidikan }\end{array}$} & \multicolumn{8}{|c|}{ Tingkat Ketahanan Pangan } & & \\
\hline & \multicolumn{2}{|c|}{$\begin{array}{c}\text { Rawan Pangan } \\
\text { Berat }\end{array}$} & \multicolumn{2}{|c|}{$\begin{array}{c}\text { Rawan Pangan } \\
\text { Sedang }\end{array}$} & \multicolumn{2}{|c|}{$\begin{array}{c}\text { Rawan Pangan } \\
\text { Ringan }\end{array}$} & \multicolumn{2}{|c|}{ Tahan Pangan } & \multicolumn{2}{|c|}{ Total } \\
\hline & $\mathbf{n}$ & $\%$ & $\mathbf{n}$ & $\%$ & $\mathbf{n}$ & $\%$ & $n$ & $\%$ & $\mathbf{n}$ & $\%$ \\
\hline \multicolumn{11}{|c|}{ KRT } \\
\hline TS & 1 & 3.8 & 1 & 20 & 2 & 28.6 & 7 & 11.1 & 11 & 10.9 \\
\hline SD & 20 & 76.9 & 3 & 60 & 5 & 71.4 & 46 & 73 & 74 & 73.3 \\
\hline SMP & 4 & 15.4 & 0 & 0 & 0 & 0 & 5 & 7.9 & 9 & 8.9 \\
\hline SMA & 1 & 3.8 & 1 & 20 & 0 & 0 & 5 & 7.9 & 7 & 6.9 \\
\hline Total & 26 & 100 & 5 & 100 & 7 & 100 & 63 & 100 & 101 & 100 \\
\hline \multicolumn{11}{|c|}{ IRT } \\
\hline TS & 7 & 26.9 & 1 & 20 & 1 & 14.3 & 11 & 17.5 & 20 & 19.8 \\
\hline SD & 15 & 57.7 & 3 & 60 & 6 & 85.7 & 46 & 73 & 70 & 69.3 \\
\hline SMP & 2 & 7.7 & 1 & 20 & 0 & 0 & 4 & 6.3 & 7 & 6.9 \\
\hline SMA & 1 & 3.8 & 0 & 0 & 0 & 0 & 2 & 3.2 & 3 & 3 \\
\hline PT & 1 & 3.8 & 0 & 0 & 0 & 0 & 0 & 0 & 1 & 1 \\
\hline Total & 26 & 100 & 5 & 100 & 7 & 100 & 63 & 100 & 101 & 100 \\
\hline
\end{tabular}

Tabel 6. Sebaran Rumah Tangga Berdasarkan Ketahanan Pangan dan Jumlah Anggota Rumah tangga

\begin{tabular}{|c|c|c|c|c|c|c|c|c|c|c|}
\hline \multirow{3}{*}{$\begin{array}{c}\text { Ukuran Rumah } \\
\text { tangga }\end{array}$} & \multicolumn{8}{|c|}{ Tingkat Ketahanan Pangan } & \multirow{2}{*}{\multicolumn{2}{|c|}{ Total }} \\
\hline & \multicolumn{2}{|c|}{$\begin{array}{c}\text { Rawan Pangan } \\
\text { Berat }\end{array}$} & \multicolumn{2}{|c|}{$\begin{array}{l}\text { Rawan Pangan } \\
\text { Sedang }\end{array}$} & \multicolumn{2}{|c|}{$\begin{array}{c}\text { Rawan Pangan } \\
\text { Ringan }\end{array}$} & \multicolumn{2}{|c|}{ Tahan Pangan } & & \\
\hline & $\mathbf{n}$ & $\%$ & $\mathbf{n}$ & $\%$ & $\mathbf{n}$ & $\%$ & $\mathbf{n}$ & $\%$ & $n$ & $\%$ \\
\hline Kecil : $\leq 4$ & 7 & 26.9 & 1 & 20.0 & 4 & 57.1 & 38 & 60.3 & 50 & 49.5 \\
\hline Sedang : 5 - 6 & 10 & 38.5 & 4 & 80.0 & 3 & 42.9 & 13 & 20.6 & 30 & 29.7 \\
\hline Besar : $\geq 7$ & 9 & 34.6 & 0 & 0 & 0 & 0 & 12 & 19.0 & 21 & 20.8 \\
\hline Jumlah & 26 & 100.0 & 5 & 100.0 & 7 & 100.0 & 63 & 100.0 & 101 & 100.0 \\
\hline
\end{tabular}


anggota rumah tangga maka semakin kecil peluang tercapainya ketahanan pangan rumah tangga. Hal ini seiring dengan pernyataan Hartog, Staveren, dan Brouwer (1995) yang menyatakan bahwa besar keluarga akan mempengaruhi kebiasaan makan dan gizi, khususnya pada rumah tangga miskin yang bergantung pada pendapatan tunai untuk membeli bahan pangan. Martianto dan Ariani (2004) juga menyatakan bahwa pangan yang tersedia untuk satu keluarga, mungkin tidak akan cukup memenuhi kebutuhan seluruh anggota keluarga tersebut tetapi hanya mencukupi sebagian dari anggota keluarga itu. Dari data BPS (2007) menunjukkan masih tingginya tingkat pertumbuhan penduduk Kabupaten Lebak yaitu 1.72.

\section{Dukungan Sosial}

Dukungan sosial merupakan berbagai macam bantuan yang diterima oleh seseorang dari orang lain. Dukungan tersebut dapat berupa dukungan secara emosional maupun instrumental (MacArthur \& John, 1998). Dukungan sosial keluarga mencakup adanya interaksi di antara tiap anggota dan saling membantu sehingga dapat tetap terjalin hubungan dan menghasilkan kepuasan batin seseorang
(Sarafino, 1996). Sebaran contoh berdasarkan bentuk dukungan sosial yang diperoleh dapat dilihat pada Tabel 7.

Dari Tabel 7 terlihat bahwa dukungan yang terbanyak diperoleh contoh berupa dukungan emosional seperti Sanak famili mau mendengar masalah-masalah (78.2\%), kehidupan dalam masyarakat memberi perasaan aman (82.2\%) dan berhubungan akrab dengan famili (82.2\%). Dukungan instrumen yang diperoleh sebagian besar contoh adalah Selalu mendapat bantuan keuangan dari orang tua atau sanak famili ketika mendapat kesulitan (56.4\%).

Dukungan sosial ini dikelompokkan menjadi rendah, sedang, dan tinggi, maka sebagian besar contoh (56.4\%) memiliki dukungan sosial yang baik, sebanyak $22.8 \%$ contoh memiliki dukungan sosial yang rendah, dan sisanya 20.8 persen contoh memiliki dukungan sosial sedang (Tabel 8). Jika dukungan sosial dihubungkan dengan status ketahanan pangan rumah tangga, maka terlihat dari Tabel 9 bahwa sebagian besar contoh baik pada rumah tangga rawan pangan berat $(57.7 \%)$, sedang $(60 \%)$, ringan (57.1\%), maupun tahan pangan (55.6\%) mempunyai dukungan sosial yang baik.

Tabel 7. Sebaran Contoh menurut Dukungan Sosial yang Diterima

\begin{tabular}{|c|c|c|c|c|c|c|}
\hline \multirow{2}{*}{ Dukungan Sosial } & \multicolumn{2}{|c|}{ Pasindangan } & \multicolumn{2}{|c|}{ Banjarsari } & \multicolumn{2}{|c|}{ Total } \\
\hline & Ya (\%) & Tidak (\%) & Ya (\%) & Tidak (\%) & Ya (\%) & Tidak (\%) \\
\hline Bantuan makanan & 56.0 & 44.0 & 31.4 & 62.7 & 43.6 & 53.5 \\
\hline Petugas kesehatan selalu mengunjungi & 2.0 & 92.0 & 5.9 & 90.2 & 4.0 & 91.1 \\
\hline Ketua RT selalu memberi semangat & 12.0 & 74.0 & 11.8 & 64.7 & 11.9 & 69.3 \\
\hline $\begin{array}{l}\text { Anak-anak bisa sekolah tanpa membayar SPP } \\
\text { dan biaya lainnya }\end{array}$ & 58.0 & 34.0 & 23.5 & 37.3 & 40.6 & 35.6 \\
\hline Sanak famili mau mendengar masalah-masalah & 86.0 & 2.0 & 70.6 & 15.7 & 78.2 & 8.9 \\
\hline $\begin{array}{l}\text { Sanak famili berupaya memperlihatkan } \\
\text { perasaan cinta dan kepeduliannya }\end{array}$ & 80.0 & 2.0 & 60.8 & 9.8 & 70.3 & 5.9 \\
\hline $\begin{array}{l}\text { Diluar rumah tanggamempunyai beberapa } \\
\text { teman karib yang sangat peduli dan mencintai }\end{array}$ & 34.0 & 48.0 & 15.7 & 49.0 & 24.8 & 48.5 \\
\hline $\begin{array}{l}\text { Kehidupan dalam masyarakat memberi } \\
\text { perasaan aman }\end{array}$ & 86.0 & 0.0 & 78.4 & 0.0 & 82.2 & 0.0 \\
\hline $\begin{array}{l}\text { Mencoba untuk berhubungan dengan sanak } \\
\text { famili seakrab mungkin }\end{array}$ & 84.0 & 2.0 & 80.4 & 5.9 & 82.2 & 4.0 \\
\hline $\begin{array}{l}\text { Jika menghadapi masalah tetangga selalu } \\
\text { memberi pertolongan }\end{array}$ & 68.0 & 18.0 & 27.5 & 45.1 & 47.5 & 31.7 \\
\hline $\begin{array}{l}\text { Selalu mendapat bantuan keuangan dari orang } \\
\text { tua atau sanak famili ketika mendapat } \\
\text { kesulitan }\end{array}$ & 48.0 & 36.0 & 64.7 & 13.7 & 56.4 & 24.8 \\
\hline $\begin{array}{l}\text { Tetangga mau membantu meminjamkan uang } \\
\text { atau barang ketika menghadapi kesulitan }\end{array}$ & 34.0 & 50.0 & 23.5 & 49.0 & 28.7 & 49.5 \\
\hline $\begin{array}{l}\text { Merasa tenang dalam lingkungan tempat } \\
\text { tinggal yang sesuai sebagai tempat } \\
\text { menumbuhkembangkan anak-anak }\end{array}$ & 66.0 & 10.0 & 60.8 & 7.8 & 63.4 & 8.9 \\
\hline $\begin{array}{l}\text { Jika dalam kesulitan selalu mendapatkan } \\
\text { pertolongan dari masyarakat dimana saya } \\
\text { tinggal }\end{array}$ & 70.0 & 10.0 & 47.1 & 19.6 & 58.4 & 14.9 \\
\hline $\begin{array}{l}\text { Saran yang diberikan tetangga sangat } \\
\text { membantu dalam menyelesaikan masalah yang } \\
\text { dihadapi }\end{array}$ & 44.0 & 36.0 & 2.0 & 54.9 & 22.8 & 45.5 \\
\hline
\end{tabular}


Tabel 8. Sebaran Contoh menurut Kategori Dukungan Sosial

\begin{tabular}{lcccccc}
\hline Dukungan & \multicolumn{2}{c}{ Pasindangan } & \multicolumn{2}{c}{ Banjarsari } & \multicolumn{2}{c}{ Total } \\
\cline { 2 - 7 } Sosial & $\mathbf{n}$ & $\%$ & $\mathbf{n}$ & $\%$ & $\mathbf{n}$ & $\%$ \\
\hline Buruk & 9 & 18.0 & 14 & 27.5 & 23 & 22.8 \\
Sedang & 5 & 10.0 & 16 & 31.4 & 21 & 20.8 \\
Baik & 36 & 72.0 & 21 & 41.2 & 57 & 56.4 \\
\hline \multicolumn{1}{c}{ Jumlah } & 50 & 100.0 & 51 & 100.0 & 101 & 100.0 \\
\hline
\end{tabular}

Berdasarkan analisis korelasi Spearman antara dukungan sosial dengan ketahanan pangan maka diperoleh hasil $r=-0.035$ dan $p>0.05$. Hal ini menunjukkan bahwa tidak terdapat hubungan yang signifikan antara dukungan sosial dan ketahanan pangan rumah tangga. Kondisi ini diduga karena dukungan sosial yang diterima oleh contoh dominan berupa dukungan emosi, sehingga secara langsung tidak berhubungan dengan konsumsi rumah tangga sehingga tidak berhubungan signifikan dengan ketahanan pangan.

\section{Pengetahuan Gizi}

Berdasarkan pengelompokkan pengetahuan gizi yaitu rendah, sedang dan tinggi, maka sebagian besar contoh (87.1\%) memiliki tingkat pengetahuan gizi rendah, $8.9 \%$ contoh memiliki tingkat pengetahuan gizi sedang dan sisanya (4\%) contoh memiliki pengetahuan gizi tinggi. Bila pengetahuan gizi ibu dihubungkan dengan status ketahanan pangan rumah tangga, maka terlihat dari Tabel 10 baik pada rumah tangga tahan pangan maupun rawan pangan ringan, sedang dan berat sebagian besar $85.7 \%$, 85.7\%, 80.0\% dan $92.3 \%$ contoh mempunyai tingkat pengetahuan gizi rendah.
Berdasarkan analisis korelasi Spearman diperoleh $r=0.077$ dan $p>0.05$ antara pengetahuan gizi ibu dengan ketahanan pangan rumah tangga. Hasil tersebut menunjukkan bahwa tidak terdapat hubungan yang signifikan antara pengetahuan gizi ibu dengan ketahanan pangan rumah tangga. Keadaan ini diduga terjadi karena sebagian besar contoh memilih jenis pangan yang dikonsumsi hanya berdasarkan ketersediaan pangan yang terdapat di wilayahnya dan berdasarkan kebiasaan makan.

\section{Akses Ekonomi}

Fungsi dari akses terhadap sumber nafkah adalah daya beli rumah tangga, berarti akses pangan terjamin seiring terjaminnya pendapatan dalam jangka panjang, keterjangkauan pangan bergantung pada kesinambungan sumber nafkah.

\section{Pekerjaan Kepala Rumah tangga}

Pekerjaan utama kepala rumah tangga di kedua desa adalah petani. Untuk pekerjaan tambahan, di Desa Pasindangan pekerjaan tambahan kepala rumah tangga yang paling besar sebarannya adalah sebagai pedagang (42\%) kemudian sebagai buruh (14\%), dan sisanya masing-masing (2\%) sebagai security, tukang urut, dan pensiunan. Di Desa Banjarsari, pekerjaan tambahan yang paling banyak dilakukan oleh contoh ialah sebagai buruh (39.2\%), kemudian pedagang $(11.8 \%)$, sisanya masingmasing sebanyak $2 \%$ bekerja sebagai wiraswasta, guru, penghulu, dan supir. Namun masih cukup banyak contoh dari keseluruhan contoh

Tabel 9. Sebaran Rumah tangga Berdasarkan Ketahanan Pangan dan Dukungan Sosial

\begin{tabular}{|c|c|c|c|c|c|c|c|c|c|c|}
\hline \multirow{3}{*}{$\begin{array}{l}\text { Dukungan } \\
\text { Sosial }\end{array}$} & \multicolumn{8}{|c|}{ Tingkat Ketahanan Pangan } & \multirow{2}{*}{\multicolumn{2}{|c|}{ Total }} \\
\hline & \multicolumn{2}{|c|}{$\begin{array}{c}\text { Rawan Pangan } \\
\text { Berat }\end{array}$} & \multicolumn{2}{|c|}{$\begin{array}{l}\text { Rawan Pangan } \\
\text { Sedang }\end{array}$} & \multicolumn{2}{|c|}{$\begin{array}{c}\text { Rawan Pangan } \\
\text { Ringan }\end{array}$} & \multicolumn{2}{|c|}{ Tahan Pangan } & & \\
\hline & $\mathbf{n}$ & $\%$ & $\mathbf{n}$ & $\%$ & $\mathbf{N}$ & $\%$ & $\mathbf{n}$ & $\%$ & $\mathbf{n}$ & $\%$ \\
\hline Buruk & 6 & 23.1 & 1 & 20.0 & 0 & 0.0 & 16 & 25.4 & 23 & 22.8 \\
\hline Sedang & 5 & 19.2 & 1 & 20.0 & 3 & 42.9 & 12 & 19.0 & 21 & 20.8 \\
\hline Baik & Q5 & 57.7 & 3 & 60.0 & 4 & 57.1 & 35 & 55.6 & 57 & 56.4 \\
\hline Total & 26 & 100.0 & 5 & 100.0 & 7 & 100.0 & 63 & 100.0 & 101 & 100.0 \\
\hline
\end{tabular}

Tabel 10. Sebaran Rumah tangga Berdasarkan Tingkat Pengetahuan Gizi dan Ketahanan Pangan

\begin{tabular}{|c|c|c|c|c|c|c|c|c|c|c|}
\hline \multirow{3}{*}{$\begin{array}{c}\text { Pengetahuan } \\
\text { Gizi }\end{array}$} & \multicolumn{8}{|c|}{ Tingkat Ketahanan Pangan } & & \\
\hline & \multicolumn{2}{|c|}{$\begin{array}{c}\text { Rawan Pangan } \\
\text { Berat }\end{array}$} & \multicolumn{2}{|c|}{$\begin{array}{c}\text { Rawan Pangan } \\
\text { Sedang }\end{array}$} & \multicolumn{2}{|c|}{$\begin{array}{c}\text { Rawan Pangan } \\
\text { Ringan }\end{array}$} & \multicolumn{2}{|c|}{$\begin{array}{l}\text { Tahan } \\
\text { Pangan }\end{array}$} & \multicolumn{2}{|c|}{ Total } \\
\hline & $n$ & $\%$ & $\mathbf{n}$ & $\%$ & $\mathbf{n}$ & $\%$ & $\mathbf{n}$ & $\%$ & $\mathbf{n}$ & $\%$ \\
\hline Rendah & 24 & 92.3 & 4 & 80.0 & 6 & 85.7 & 54 & 85.7 & 88 & 87.1 \\
\hline Sedang & 2 & 7.7 & 1 & 20.0 & 1 & 14.3 & 5 & 7.9 & 9 & 8.9 \\
\hline Tinggi & 0 & 0.0 & 0 & 0.0 & 0 & 0.0 & 4 & 6.3 & 4 & 4.0 \\
\hline Total & 26 & 100.0 & 5 & 100.0 & 7 & 100.0 & 63 & 100 & 101 & 100.0 \\
\hline
\end{tabular}


yang tidak memiliki pekerjaan tambahan dan hanya tergantung pada pekerjaan utama sebagai petani. Sebaran pekerjaan KRT dapat dilihat pada Tabel 11.

\section{Pengeluaran Per kapita}

Pengeluaran perkapita rumah tangga contoh rata-rata sebesar Rp 254 241. Pengeluaran terkecil sebesar Rp 40394 dan terbesar ialah sebesar Rp 1140 028. Proporsi rata-rata pengeluaran pangan rumah tangga ialah sebesar $39.55 \%$, proporsi pengeluaran terkecil ialah $8.10 \%$ pada contoh di Desa Pasindangan dan terbesar adalah $84.26 \%$ pada contoh di Desa Banjarsari.

Untuk mengetahui lebih jelas kondisi ekonomi rumah tangga contoh, maka dapat dilihat pada Tabel 12. Klasifikasi rumah tangga miskin dan tidak miskin didasarkan pada perbandingan pengeluaran perkapita dengan garis kemiskinan. Garis kemiskinan yang digunakan adalah garis kemiskinan tingkat propinsi Ban- ten tahun 2008 yaitu Rp 156 494. Dikatakan miskin bila pengeluaran perkapita rumah tangga dibawah garis kemiskinan, dan dikatakan tidak miskin bila pengeluaran per kapita rumah tangga diatas garis kemiskinan.

Berdasarkan klasifikasi tersebut maka sebagian besar (68.3\%) contoh di kedua desa merupakan rumah tangga tidak miskin dan sisanya (31.7\%) contoh merupakan rumah tangga miskin.

Bila kemiskinan rumah tangga dihubungkan dengan status ketahanan pangan rumah tangga, maka terlihat dari Tabel 13 bahwa sebagian besar rumah tangga rawan pangan berat (53.8\%) berada pada kondisi miskin, dan pada rumah tangga tahan pangan sebagian besar $(77.8 \%)$ dalam kondisi tidak miskin.

Hasil analisis korelasi Pearson antara pengeluaran rumah tangga dan ketahanan pangan rumah tangga $r=0.251$ dan $p<0.05$, ini menunjukkan bahwa ada hubungan yang signifikan

Tabel 11. Klasifikasi Pekerjaan Kepala Rumah tangga

\begin{tabular}{|c|c|c|c|c|c|c|}
\hline \multirow{2}{*}{ Jenis Pekerjaan } & \multicolumn{2}{|c|}{ Pasindangan } & \multicolumn{2}{|c|}{ Banjarsari } & \multicolumn{2}{|c|}{ Total } \\
\hline & $\mathbf{n}$ & $\%$ & $\mathbf{n}$ & $\%$ & $\mathbf{n}$ & $\%$ \\
\hline \multicolumn{7}{|c|}{ Pekerjaan utama } \\
\hline Petani & 50 & 100.0 & 51 & 100.0 & 101 & 100.0 \\
\hline \multicolumn{7}{|c|}{ Pekerjaan tambahan } \\
\hline Tidak ada & 19 & 38.0 & 21 & 41.2 & 40 & 39.6 \\
\hline Pedagang & 21 & 42.0 & 6 & 11.8 & 27 & 26.7 \\
\hline Buruh & 7 & 14.0 & 20 & 39.2 & 27 & 26.7 \\
\hline Wiraswasta & 0 & 0.0 & 1 & 2.0 & 1 & 1.0 \\
\hline Guru & 0 & 0.0 & 1 & 2.0 & 1 & 1.0 \\
\hline Security & 1 & 2.0 & 0 & 0.0 & 1 & 1.0 \\
\hline Tukang urut & 1 & 2.0 & 0 & 0.0 & 1 & 1.0 \\
\hline Pensiunan & 1 & 2.0 & 0 & 0.0 & 1 & 1.0 \\
\hline Penghulu & 0 & 0.0 & 1 & 2.0 & 1 & 1.0 \\
\hline Supir & 0 & 0.0 & 1 & 2.0 & 1 & 1.0 \\
\hline Jumlah & 50 & 100.0 & 51 & 100.0 & 101 & 100.0 \\
\hline
\end{tabular}

Tabel 12. Sebaran Contoh menurut kategori kemiskinan Rumah tangga

\begin{tabular}{lcccccc}
\hline \multirow{2}{*}{ Kategori } & \multicolumn{2}{c}{ Pasindangan } & \multicolumn{2}{c}{ Banjarsari } & \multicolumn{2}{c}{ Total } \\
\cline { 2 - 6 } & $\mathbf{n}$ & $\%$ & $\mathbf{n}$ & $\%$ & $\mathbf{n}$ & $\%$ \\
\hline Miskin & 14 & 28.0 & 18 & 35.3 & 32 & 31.7 \\
Tdk miskin & 36 & 72.0 & 33 & 64.7 & 69 & 68.3 \\
\hline Jumlah & 50 & 100.0 & 51 & 100.0 & 101 & 100.0 \\
\hline
\end{tabular}

Tabel 13. Sebaran Rumah tangga Berdasarkan Ketahanan Pangan dan Kemiskinan

\begin{tabular}{lcccccccccc}
\hline \multirow{2}{*}{$\begin{array}{c}\text { Klasifikasi } \\
\text { kemiskinan }\end{array}$} & $\begin{array}{c}\text { Rawan } \\
\text { Pangan Berat }\end{array}$ & \multicolumn{1}{c}{$\begin{array}{c}\text { Rawan Pangan } \\
\text { Sedang }\end{array}$} & $\begin{array}{c}\text { Rawan Pangan } \\
\text { Ringan }\end{array}$ & \multicolumn{2}{c}{ Tahan Pangan } & Total \\
\cline { 2 - 11 }$n$ & $\mathbf{n}$ & $\%$ & $\mathbf{n}$ & $\%$ & $\mathbf{n}$ & $\%$ & $\mathbf{n}$ & $\%$ & $\mathbf{n}$ & $\%$ \\
\hline Miskin & 14 & 53.8 & 2 & 40.0 & 2 & 28.6 & 14 & 22.2 & 32 & 31.7 \\
Tidak miskin & 12 & 46.2 & 3 & 60.0 & 5 & 71.4 & 49 & 77.8 & 69 & 68.3 \\
\hline Total & 26 & 100.0 & 5 & 100.0 & 7 & 100.0 & 63 & 100.0 & 101 & 100.0 \\
\hline
\end{tabular}


antara pengeluaran rumah tangga dengan ketahanan pangan rumah tangga. Keadaan ini sesuai dengan hasil penelitian Andrews et al., (2000) dalam Kennedy (2003) menunjukkan bahwa terdapat hubungan antara ketidaktahanan pangan dengan pendapatan. Kejadian ketidaktahanan pangan 12 kali lebih besar dan kelaparan 9 kali lebih besar pada rumah tangga yang berada dibawah garis kemiskinan dibanding dengan rumah tangga dengan pendapatan 1.85 kali lebih besar dari garis kemiskinan.

\section{Analisis J alur}

Berdasarkan diagram jalur pada Gambar 2, faktor yang diduga berpengaruh langsung terhadap ketahanan pangan rumah tangga adalah pendidikan KRT dan IRT, jumlah anggota rumah tangga, dukungan sosial, pengetahuan gizi ibu, dan pengeluaran per kapita.

Hasil analisis jalur menunjukkan bahwa pendidikan KRT, dukungan sosial, dan pengetahuan gizi ibu tidak memiliki pengaruh yang signifikan terhadap ketahanan pangan rumah tangga ( $p>0.05)$. Jumlah anggota rumah tangga dan pengeluaran per kapita berpengaruh langsung terhadap ketahanan pangan rumah tangga $(p<0.05)$. Secara tidak langsung jalur yang paling berpengaruh terhadap ketahanan pangan rumah tangga adalah dimulai dari ukuran rumah tangga pengeluaran rumah tangga ketahanan pangan rumah tangga.

\section{KESIMPULAN}

Prevalensi rumah tangga tahan pangan adalah $62.4 \%$, rawan pangan $37.6 \%$ yang terdiri dari $25.7 \%$ rumah tangga rawan pangan berat, 6.9\% rumah tangga rawan pangan ringan dan $5 \%$ rumah tangga rawan pangan sedang.

Tidak terdapat hubungan yang signifikan antara pendidikan KRT, pendidikan IRT, pengetahuan gizi ibu dan dukungan sosial dengan ketahanan pangan rumah tangga. Terdapat hubungan yang signifikan antara jumlah anggota rumah tangga dan pengeluaran per kapita dengan ketahanan pangan rumah tangga.

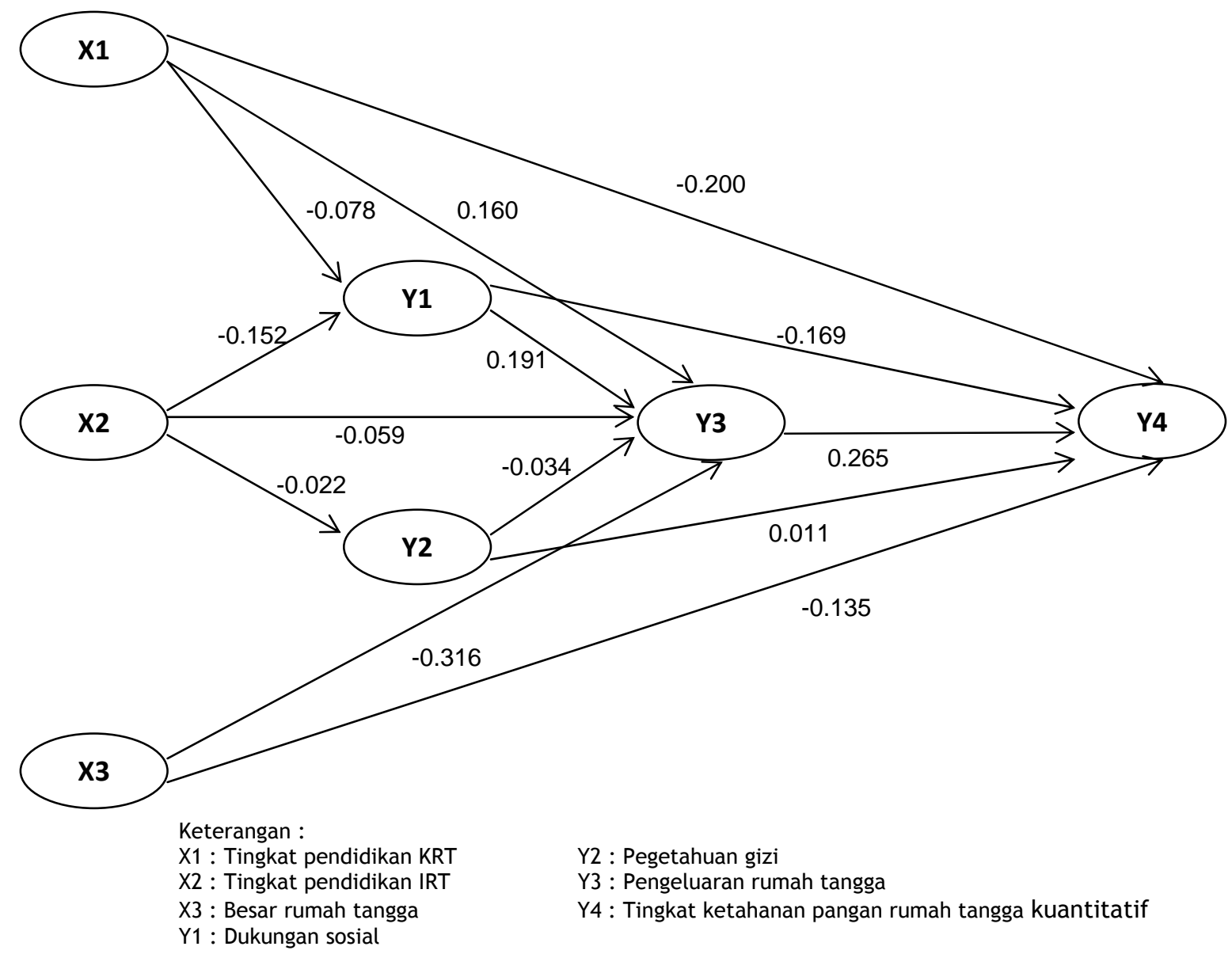

Gambar 2. Diagram Jalur Analisis Jalur Faktor-faktor yang Mempengaruhi Ketahanan Pangan Rumah Tangga 
Pengaruh langsung terbesar terhadap ketahanan pangan rumah tangga adalah pengeluaran rumah tangga. Jalur tidak langsung yang paling berpengaruh terhadap ketahanan pangan rumah tangga adalah dimulai dari penurunan jumlah anggota rumah tangga - pengeluaran per kapita - ketahanan pangan rumah tangga.

Upaya yang dapat dilakukan untuk memperbaiki dan mengatasi kondisi ketahanan pangan rumah tangga diantaranya dengan menggalakkan kembali program Keluarga Berencana (KB), meningkatkan kualitas kader posyandu agar dapat memberian pengetahuan pada ibu di wilayah kerjanya, mengaktifkan kembali fungsi PKK, revitalisasi kelembagaan bagi petani seperti kelompok tani sebagai wadah aspirasi dan pusat memperoleh informasi, pemberian bantuan kredit, dan teknologi pada petani untuk peningkatan produktivitas dan pendapatan petani.

\section{DAFTAR PUSTAKA}

[BPS] Badan Pusat Statistik. 2007. Kabupaten Lebak dalam Angka. Badan Pusat Statistik Kabupaten Lebak, Banten.

[BPS] Badan Pusat Statistik. 2008. Profil Kemiskinan Indonesia, Maret 2008. Berita Resmi Statistik. Badan Pusat Statistik. No. 37/07/Th. XI, 1 Juli 2008.

Den Hartog AP, van Staveren WA, \& Brouwer (1995). Manual for Social Surveys on Food Habits and Consumption in Developing Countries. Margraf Verlag, Germany.

[DEPKES] Departemen Kesehatan. 2003. Gizi dalam Angka, sampai dengan Tahun 2002. Departemen Kesehatan RI, Direktorat Jenderal Bina Kesehatan Masyarakat, Direktorat Gizi Masyarakat, Jakarta.

Departemen Pertanian. 2007. Buku Pedoman Analisis Akses Pangan Pedesaan. Deptan, Jakarta.
[FAO] Food and Agriculture Organisation. 2003. Proceedings, Measurement and Assesment of Food Devrivation and Undernutrition. International Scientific symposium. Rome, 26-28 Juni 2002.

Hardinsyah. 2001. Pembangunan Pangan di Era Ekonomi Daerah Prosuding Dialog dan Loka Karya Kebijakan dan Program Pangan, Ketahanan Pangan di Era Ekonomi. Pusat Studi Kebijakan Pangan dan Gizi IPB, Bogor.

Kennedy, Eileen. 2003. Qualitative Measures of Food Insecurity and Hunger. Dalam Proceeding, Measurement and Assessment of Food Devrivation and Undernutrition. International Scientific Symposium. Rome, 26-28 Juni 2002

MacArthur T dan John D. 1998. Social support \& social conflict. www.macses.ucsf.edu/ research/psychosocial/notebook/socspp. [7 Feb 2008].

Martianto D \& M Ariani. 2004. Analisis Konsumsi Pangan Rumah Tangga. Widyakarya Nasional Pangan dan Gizi VII, Jakarta.

Sarafino EP. 1996. Health Psycology: Biopsychosocial Interactions. Allyn and Bacon, New York.

World Food Programme. 2005. Emergency Food Security Assessment Handbook: Me thodological Guidance for Better Assessment. First edition. http://www.Wfp. org./operations/emergency_needs/EFSA _Communication_brief.pdf [14 November 2007].

Yamin S \& Kurniawan H. 2009. SPSS Complete: Teknik Analisis Statistik Terlengkap dengan Software SPSS. Salemba Infotek, Jakarta. 